\title{
Treatment of ascites by reinfusion of concentrated peritoneal fluid- review of 318 procedures in 210 patients
}

\author{
V. G. LÉVY \\ M.D. \\ N. Pauleau \\ M.B., B.S.
}

\author{
P. OPOLON \\ M.D. \\ J. CAROLI \\ M.D.
}

Hôpital St Antoine, 184 rue du Faubourg, St Antoine F75012, Paris

\begin{abstract}
Summary
A modified plate dialyser (Rhône-Poulenc) was used 318 times to concentrate ascites for reinfusion in $\mathbf{2 1 0}$ patients, most of them having longstanding ascites refractory to diuretic treatment.

The advantages of this method of treatment are its rapidity and efficacy, ascites being reduced in a mean time of $21 \pm 13 \mathrm{hr}$. Hyponatraemia is easily corrected by a sodium load during reinfusion. There was improvement in renal function in 11 of 37 cases. Adverse effects are fever, pulmonary oedema, peritoneal infections and coagulation disorders. Ascites recurred in $84 \%$ of the cases, but the procedure shortens hospital stay and reduces the cost of the treatment.
\end{abstract}

Ascites reinfusion has been practised for many years. One effect of such treatment is to expand the plasma volume which may result in an improvement of renal function. A problem with ascites reinfusion has been the large intravenous fluid load that the patient receives. In conjunction with Rhône-Poulenc an apparatus has therefore been developed in which the ascitic fluid is first passed through a haemodialysis membrane, so that the protein of the fluid can be concentrated by ultrafiltration, before reinfusing (Lévy et al., 1971). In this way excessive water and electrolytes can be discarded.

\section{Patients}

Two hundred and ten patients have been treated with 318 reinfusions. The underlying pathology was as follows: alcoholic cirrhosis (155 cases), posthepatic cirrhosis (thirty-one), biliary cirrhosis (two), Budd-Chiari syndrome (seven), abdominal tumours (seven), pancreatitis (one), constrictive pericarditis (one) and miscellaneous (six).

At the time of reinfusion renal function was often poor, in ninety-eight instances the plasma urea concentration being greater than $50 \mathrm{mg} / 100 \mathrm{ml}$, and in fourteen greater than $150 \mathrm{mg} / 100 \mathrm{ml}$. Plasma sodium concentration was less than $130 \mathrm{mEq} / \mathrm{l}$ in eighty-one $\mathbb{C}_{\infty}$ instances. Liver function was usually similarly poor, in thirty-seven patients being moribund, and only $\AA$ thirty-two in good clinical condition with isolated음 ascites.

Ascites had been present for more than 6 months in $63 \%$ of cases and all except two had previouslyo received diuretics. In most cases diuretics were either $\stackrel{\omega}{\oplus}$ ineffective or had caused azotaemia and/or hypg- $\overrightarrow{0}$ natraemia. Other indications for treatment were the $v$ necessity of prompt drainage in order that either surgery (fourteen cases) or laparoscopy (fourteen) could be carried out, or as a trial of treatment for renal failure (twenty-eight) or hyponatraemia (fif-o teen).

\section{Technical aspects}

The apparatus may be used in two ways. If a high filtration pressure is used then a high protein content fluid is reinfused, at the same time relatively large volumes of water and electrolytes are discarded. Although large volumes of ascites are quickly removed, the high protein reinfusate may cause 3 fever and the dialysis membrane may become blocked. Alternatively, with a low filtration pressure, $\mathrm{O}$ the membrane will remain patent for longer periods of time, but larger volumes of fluid will be reinfused은 with the risk of inducing pulmonary oedema. AD compromise by achieving a concentration of 2- to 3fold with a reinfusion flow rate of $300-400 \mathrm{ml} / \mathrm{hr}$ is N suitable in most patients.

\section{Results}

The procedure was continued until fluid ceased to $\bar{\sigma}$ circulate in all except seven cases. The following measurements were made (mean \pm s.d.) from eighty reinfusions: duration $21 \pm 13 \mathrm{hr}$, weight loss $7 \cdot 34 \pm$ $3.71 \mathrm{~kg}$, decrease in abdominal girth $10.6 \pm 5.3 \mathrm{~cm}$ volume of filtrate $6570 \pm 3360 \mathrm{ml}$. In sixty cases the mean increase in plasma volume during reinfusion 
was $471( \pm 468) \mathrm{ml}$, but this was transient and returned to basal levels within 10 days. Creatinine clearance also improved transiently from $44 \pm 26$ $\mathrm{ml} / \mathrm{min}$ to $73 \pm 35 \mathrm{ml} / \mathrm{min}$ but again had usually fallen to basal levels within a week. Urine volume doubled in $35 \%$ of cases, but a significant natriuresis (greater than $50 \mathrm{mEq} /$ day) was achieved in only $24 \%$.

In the most dramatic case the reinfusion was continued for $64 \mathrm{hr}$ and 281 of filtrate removed. In the same patient another reinfusion was performed 4 months later which lasted $91 \mathrm{hr}$. Thirty-eight litres of filtrate were removed and the patient also passed $24 \cdot 31$ of urine containing $2465 \mathrm{mEq}$ of sodium.

\section{Reinfusion and hyponatraemia}

Plasma sodium concentration often fell 7 days after reinfusion (Fig. 1). This could be prevented by giving a sodium load during the reinfusion. The

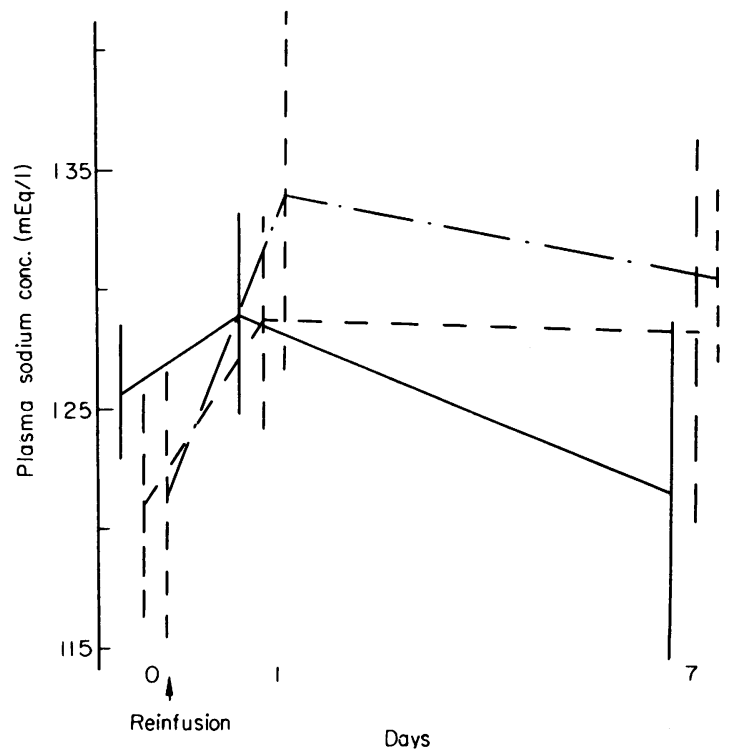

FIG. 1. Plasma sodium concentration before, and 1 and 7 days following reinfusion. Effect of sodium infusion. (Vertical lines indicate s.d.) High sodium load (twentynine cases), - - - - - ; low sodium load (nineteen cases), _ _ _ ; without sodium (twenty-four cases),

amount of sodium given was calculated on the basis of body weight and it was found that $0.7 \mathrm{mEq}$ of sodium $/ \mathrm{kg}$ body weight are needed to increase plasma sodium concentration by $1 \mathrm{mEq} / \mathrm{l}$. Excessive potassium loss resulting in hypokalaemia did not occur.

\section{Reinfusion and renal failure}

In patients with functional renal failure, one might expect renal function to improve secondary to the increase in plasma volume. The results, however, were disappointing. Thirty-seven patients with a plasma urea concentration greater than $80 \mathrm{mg} / 100$ $\mathrm{ml}$ were so treated. In only eleven cases was there a marked improvement in renal function. In eight cases renal function deteriorated.

\section{Adverse effects}

Pyrexia occurred in $50 \%$ of reinfusions, but this disappeared soon afterwards. Pulmonary oedema developed in twelve cases and haemolytic jaundice in two.

Overt gastrointestinal haemorrhage occurred in eleven cases. Laboratory changes in coagulation factors were much more frequent (Table 1), and clinical manifestations of fibrinolysis or intravascular coagulation were present in eight cases, but these were controlled in all but one patient with $\varepsilon$-amino caproic acid (Buffet et al., 1973).

TABle 1. Coagulation disorders

\begin{tabular}{lc}
\hline & No. of cases \\
$\begin{array}{l}\text { Clinical manifestations } \\
\text { (one death) }\end{array}$ & $\mathbf{8}$ \\
Laboratory changes (134 studies) & 59 \\
Decreased platelets & 44 \\
Decreased fibrinogen & 34 \\
Decreased factor V & 32 \\
Decreased factor II or VII + X & 18 \\
Positive ethanol test & 15 \\
Positive Von Kaulla $(<2$ h) & 5 \\
\hline
\end{tabular}

Peritoneal infection appeared to be a consequence of the procedure in fourteen cases, and this was a major factor in contributing towards death in five. Bacterial growth on the catheter tip was observed in nineteen instances.

Serious mechanical incidents were relatively rare, but included perforated sigmoid diverticulum (two cases), strangulated umbilical hernia (three), rupture of epigastric artery (one), and a fatal subclavian haematoma (one). Minor mechanical adverse effects were common but never serious, e.g. phlebitis, loss of fluid into the abdominal wall, scrotal oedema, pain, and transient ileus.

\section{Long term value}

Ascites reinfusion in no way corrects the liver disease or the factors leading to ascites formation. Its value is therefore only palliative. However, of 150 patients treated up to 1 January 1974 seventy-two are still alive, in most cases the ascites being controlled by diuretics, but some patients have had repeated reinfusions (one case receiving nine). The causes of death in the other seventy-eight cases were liver failure (twenty-one cases), renal failure (twentyone), hepatoma (seven), haemorrhage (fifteen), and others (fourteen). 


\section{Acknowledgments}

We are very indebted to Drs J. Escamilla, P. Gateau, P. Hadchouel, M. Thomas, M. Smadja, V. Nusinovici (Liver Intensive Care Unit, Hôpital St-Antoine, Paris); Drs D. Vergoz (C.D.T.S., Paris) and J. Conard (Hôtel-Dieu, Paris) for coagulation studies; Dr J. P. Touboul (Hôpital StAntoine, Paris) for biochemical studies; Drs A. Sausse, A. Stern, A. Granger (Génie Médical-Laboratoire Rhône Poulenc, F 94-Vitry-sur-Seine).

\section{References}

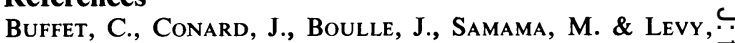
V.G. (1973) Accidents de la coagulation au cours des $\overrightarrow{\overline{\vec{N}}}$ réinjections d'ascite concentrée. Médicine et Chirurgie Digestive. 2, 275.

Lévy, V.G., Hecht, Y., Georgacopoulos, H., Hadchouel, P., Touboul, J.P., Sausse, A., Granger, A., Stern, A. \& $\overline{\bar{c}}$ CARoli, J. (1971) Assèchement des ascites cirrhotiques par réinjection veineuse continue du liquide d'ascite concentré. $\varrho$ Annales de Médecine Interne, 122, 1075. 